Stanisław Witkowski MS ${ }^{1}$

Uniwersytet Papieski Jana Pawła II w Krakowie

\title{
Człowieczeństwo i bóstwo Syna Człowieczego \\ w Jego męce, śmierci i zmartwychwstaniu Trzy pouczenia Jezusa o swej pasji w ujęciu Markowym
}

Chrystologia Markowa ma charakter początkowy. Marek zawarł ją szczególnie w trzech tytułach, którymi określił Jezusa: Syn Boży, Mesjasz oraz Syn Człowieczy. Tytuł „Syn Boży” występuje u Marka w dosłownym brzmieniu cztery razy (por. 1, 1; 3, 11; 5, 7; 15, 39). Należy zwrócić uwagę, że dostrzegamy go na początku Ewangelii $(1,1)$ oraz niemalże przy jej końcu, w wyznaniu setnika: „prawdziwie ten człowiek był Synem Bożym” $(15,39)$. Poza tym rzeczywistość Synostwa Bożego Jezusa (,mój Syn”; ,Syn Błogosławionego") pojawia się w kluczowych miejscach Ewangelii (por.

1 Ks. Stanisław Witkowski MS (ur. 1960), dr hab. teologii biblijnej, adiunkt w Katedrze Egzegezy Nowego Testamentu UPJPII w Krakowie, studiował w Papieskim Instytucie Biblijnym w Rzymie (LNB). Interesuje się problematyką dotyczącą zagadnień synoptycznych oraz kwestiami z zakresu Pism Janowych i teologii św. Pawła. Autor m.in. publikacji: Męka Pańska według Ewangelii św. Jana, Kraków 2001; Listy do siedmiu Kościołów (Ap 2-3), Kraków 2002; Nowa jakość życia. Kazanie na Górze Mt 5-7, Kraków 2004. Autor artykułów naukowych nawiązujących głównie do Listu do Rzymian. 
$1,11 ; 9,7 ; 14,61)$. Bez wątpienia chodzi o określenie najbardziej znaczące w odniesieniu do Mistrza z Nazaretu².

Tytuł „Mesjasz” pojawia się w Ewangelii Markowej siedem razy (por. $1,1 ; 8,29 ; 9,41 ; 12,35 ; 13,21 ; 14,61 ; 15,32)$, mniej niż u pozostałych synoptyków (Mt - szesnaście razy; Łk - dwanaście razy), ale za to w samym centrum Ewangelii (por. 8, 27-30).

Natomiast tytuł „Syn Człowieczy” odnajdujemy u Marka czternaście razy i zauważamy, że przenika całą jego Ewangelię (por. 2, 10. 28; 8, 31. $38 ; 9,9.12 .31 ; 10,33.45 ; 13,26 ; 14,21$ bis. 41. 62). Jest w niej najczęstszym określeniem Jezusa. Dostrzegamy go między innymi w trzech pouczeniach dotyczących jednocześnie męki, śmierci i zmartwychwstania Jezusa (por. 8, 31-33; 9, 30-32; 10, 32-34) oraz w syntetycznym stwierdzeniu, że Syn Człowieczy przyszedł, aby „dać swoje życie na okup za wielu" (Mk 10, 45). W analizach tych wyszczególnionych tematycznie miejsc spostrzeżemy, że Mk 10, 45 stanowi kompendium trzech pouczeń odnośnie do pasji Jezusa i ukazuje jej cel.

Dotychczas nie ukazał się w języku polskim artykuł badający proponowane w tytule zagadnienie ${ }^{3}$. Komentarze zaś przekazują odnośnie do tego tematu ogólne i lapidarne spostrzeżenia ${ }^{4}$. Nowością niniejszego opracowania jest wyraźne zwrócenie uwagi, że upokorzony Syn Człowieczy w wersji Markowej zmartwychwstaje własną mocą

\footnotetext{
2 Por. K. Stock, Alcuni aspetti della cristologia Marciana, Roma 1989, s. 10.

3 Niektórzy egzegeci podejmowali ten problem, ale w innej perspektywie. P. Kasiłowski zwrócił uwagę na reakcje uczniów po wypowiedziach Jezusa na temat swego losu. Por. P. Kasiłowski, Zapowiedź śmierci Jezusa a postawy uczniów w Mk 8, 27- 10, 52, „Bobolanum” 8 (1997), s. 111-125. R. Bartnicki poruszył zagadnienie męki i zmartwychwstania Jezusa w ewangeliach synoptycznych w kontekście autentyczności logiów Jezusa oraz znaku Jonasza. Por. R. Bartnicki, Ewangeliczne zapowiedzi męki, śmierci i zmartwychwstania w świetle kryteriów autentyczności logiów Jezusa, „Collectanea Theologica” 51 (1981), fasc. II, s. 53-64.

${ }_{4}$ Por. R. Bartnicki, Przesłanie Ewangelii, Warszawa 1996, s. 240-243; H. Langkammer, Ewangelia według św. Marka. Tłumaczenie, wstęp i komentarz, [w:] Pismo Święte Nowego Testamentu w przekładzie z języków oryginalnych, Lublin 2004², s. 87; 93; 100; R. Bartnicki, Ewangelia według św. Marka. Wstęp - przekład z oryginału-komentarz, [w:] Pismo Święte Nowego Testamentu, t. 3/2, Poznań 2007 (reprint z 1977), s. 207; 226-227; 250-251; 254.

5 H. Langkamer zauważa w kontekście pierwszego pouczenia o losie Jezusa, że czasownik opisujący zmartwychwstanie Jezusa jest w stronie czynnej. Później zaś pisze, że Chrystus został wskrzeszony „trzeciego dnia”. Por. H. Langkammer, Ewangelia według św.
} 


\section{Bolesny los Syna Człowieczego (Mk 8, 31-33)}

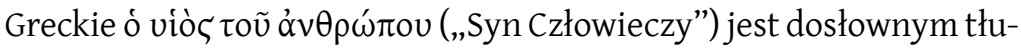

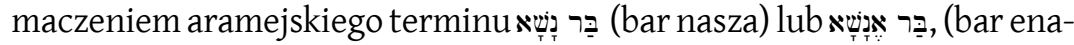
sza), który pierwotnie oznaczał człowieka ${ }^{6}$. Jezus posłużył się tym określeniem, aby opisać swoje człowieczeństwo naznaczone ekstremalnym w przypisie cierpieniem.

Wśród synoptyków jedynie Marek podkreśla, że słowa Jezusa dotyczące dramatycznego losu Syna Człowieczego i skierowane do uczniów są pouczeniem. Nie chodzi zatem o zwykłe mówienie, udzielenie informacji, ale o autorytatywne nauczanie ${ }^{7}$ (por. Mk 1, 22), które ma kształtować życie ucznia. Wyjątkowość tego pouczenia potwierdza czasownik $\delta 1 \delta \alpha ́ \sigma k \varepsilon ı v$ („nauczyć”, ,wyjaśniać”), który często występuje w dziele Markowym, ale prawie nigdy nie podaje treści Jezusowego nauczania. Mk 8, 31 stanowi w tym względzie jeden z rzadkich wyjątków.

Pierwsze pouczenie na temat losu Jezusa rozpoczyna się słowem $\delta \varepsilon \tilde{\imath}$ („trzeba” - por. także Mt 16, 21; Łk 9, 22): „trzeba, aby Syn Człowieczy

Marka. Thumaczenie, wstęp i komentarz, dz. cyt., s. 213. W nawiązaniu do drugiego pouczenia zaznacza, że „Bóg niezwłocznie wskrzesi Jezusa”. Tamże, s. 227. P. Kasiłowski przekazuje odnośnie do Mk 8, 31-33, że Jezus zapowiada również zmartwychwstanie. Por. P. Kasiłowski, Zapowiedź śmierci Jezusa a postawy uczniów w Mk 8, 27 - 10, 52, art. cyt., s. 111. R. Bartnicki stwierdza, iż „mówienie, że «Chrystus zmartwychwstał» zdradza nieco późniejsze pochodzenie chrześcijańskie oraz wpływ proroctwa Oz 6, 2 (LXX)”. A. Mień, mimo że pisze o Synu Człowieczym, to jednak całkowicie pomija analizowaną przez nas kwestię. Por. A. Mień, Syn Człowieczy, Warszawa 1994. H. Sławiński przywołuje zapowiedźlosu Jezusa (w wersji Mateuszowej) obejmującego wyszydzenie, ubiczowanie, ukrzyżowanie, śmierć i zmartwychwstanie (por. Mt 20,18-19), ale koncentruje się na Ewangelii Janowej i podkreśla wywyższenie Jezusa, oddane za pomocą czasownika ú\}oũv - „wywyższyć”. Por. H. Sławiński, Przepowiadanie Chrystusowego krzyża, Warszawa 1997, s. 144-145. Wymienieni autorzy nie stwierdzają albo nie podkreślają w sposób wyraźny, że Syn Człowieczy w Ewangelii Markowej zmartwychwstaje własną mocą.

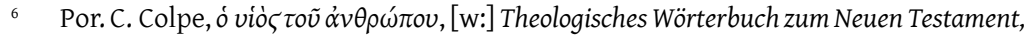
in Verbindung mit zahlreichen Fachgenossen, herausgegeben von G. Friedrich, t. 8, Stuttgart 1969, s. 408, 15-5. Później pod wpływem Dn 7, 13 określenie „jakby Syn Człowieczy” wskazywało na „istotę różną od Boga, ale będącą blisko Niego”. Por. M. Parchem, Księga Daniela, Częstochowa 2008, s. 471 (Nowy Komentarz Biblijny, Stary Testament, 26). W tradycji zaś chrześcijańskiej tytuł „Syn Człowieczy” jest równoznaczny z Jezusem Chrystusem.

Por. K. Stock, Il cammino di Gesù verso Gerusalemme. Marco 8, 27 - 10, 52, Roma 1989, s. 38. 
wiele cierpiał, był odrzucony przez starszych, arcykapłanów i uczonych w Piśmie i był zabity..." $(8,31)$.

Termin $\delta \varepsilon \tilde{i}$ nie pojawia się w kolejnych pouczeniach (por. 9, 30-32; 10, 32-34), jednak odnosi się do nich wszystkich ${ }^{8}$. Podkreśla, że cierpienia Syna Człowieczego są Bożą decyzją. Przyszły los Jezusa nie jest więc tylko rezultatem ludzkiej zmowy, lecz wypływa z woli Bożej (por. Mk 9, 11; 13 , 7. 10. 14; 14, 31). Ludzie wprawdzie działają, ale to, co czynią, zawiera się w zbawczym planie Bożym.

Wyrażenie „wiele cierpieć” ( $\pi \circ \lambda \lambda \grave{\alpha} \pi \alpha \theta \varepsilon \tilde{i} v$ - por. 9, 12) kładzie nacisk na "wiele" i syntetyzuje całą mękę Syna Człowieczego": modlitwę w Getsemani, aresztowanie, przesłuchanie przez żydowskie autorytety, proces rzymski, szyderstwa żołnierzy, ukrzyżowanie, drwiny ze strony przechodzących obok krzyża. Odpowiedzialne za los Syna Człowieczego są żydowskie autorytety: starsi, arcykapłani i uczeni w Piśmie. Te trzy instancje tworzyły sanhedryn. Starsi reprezentowali arystokrację świecką, arcykapłani - kapłańską, zaś uczeni w Piśmie byli w większości faryzeuszami, ekspertami w Prawie.

W 8, 31 po raz pierwszy mamy do czynienia z tymi trzema ugrupowaniami ${ }^{10}$. Tylko tutaj starsi wymienieni są na pierwszym miejscu. Zawsze wylicza się wpierw arcykapłanów $(11,27 ; 14,43 ; 14,53 ; 15,1)$. Arcykapłani okazują się największymi wrogami Jezusa ${ }^{11}$.

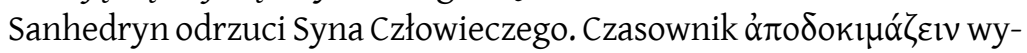

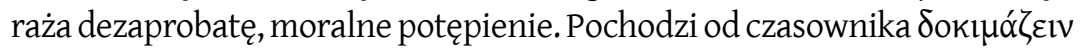
(„,badać”, ,poddać próbie”) i oznacza „odrzucić po zbadaniu”, ,uznać za niegodnego". Jezus zostanie odrzucony z rozmysłem. Ostatnim etapem Jego męki będzie zadana Mu gwałtowna śmierć.

K. Stock, Il cammino di Gesù verso Gerusalemme..., dz. cyt., s. 43.

9 Por. S. Grasso, Vangelo di Marco. Nuova versione, introduzione e commento, Milano 2003, s. 233 (I Libri Biblici, Nuovo Testamento, t. 2).

10 Te trzy instancje tworzące sanhedryn pojawiają się w kluczowych momentach drogi Jezusa w kierunku Jego śmierci: w pierwszym pouczeniu na temat losu Jezusa $(8,31)$, w pierwszym bezpośrednim spotkaniu z nimi $(11,27)$, w pochwyceniu Jezusa $(14,43)$, w drugim bezpośrednim spotkaniu z nimi w czasie procesu żydowskiego $(14,53)$ oraz w wydaniu Jezusa Piłatowi, który skazał Go na ukrzyżowanie.

11 Por. K. Stock, Il cammino di Gesù verso Gerusalemme..., dz. cyt., s. 42. 


\subsection{Wzmianka o zmartwychwstaniu}

Pierwsze pouczenie - podobnie jak i pozostałe dwa - kończy się mocnym akcentem: „a po trzech dniach zmartwychwstanie”. Należy zauważyć, że cytowane wcześniej $\delta \varepsilon \tilde{\imath}$ („trzeba”) odnosi się także do zmartwychwstania Syna Człowieczego. Plan Boży jest więc zawsze planem życia

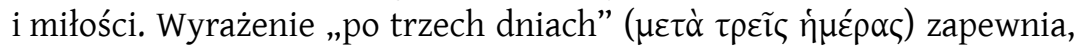
że ciało Jezusa było martwe. Zgodnie z koncepcją żydowską, kto spoczywa w grobie od trzech dni, jest uznany za pozbawionego życia ${ }^{12}$. Poza tym słowa „po trzech dniach” wskazują w tradycji biblijnej krótki odcinek czasu, po którym następuje skuteczna i zbawcza interwencja Boga (por. Oz 6, 2). W Izraelu, chociaż wierzono w życie po śmierci jako nagrodę dla sprawiedliwego, to jednak nie spodziewano się, aby zmarły mógł powrócić do życia na ziemi ${ }^{13}$. Zmartwychwstanie Jezusa jest nowością, która nie znajduje swego wzoru w losie starotestamentowego sprawiedliwego (por. Mdr 2, 12-20; 5, 1-7) ${ }^{14}$.

W pouczeniach o zmartwychwstaniu Chrystusa Marek posługuje się

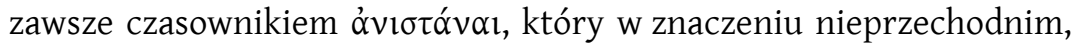
w stronie czynnej ( $\alpha$ $v \alpha \sigma \tau \tilde{\eta} v \alpha l$ - pierwsze pouczenie - 8,31) lub zwrotnej

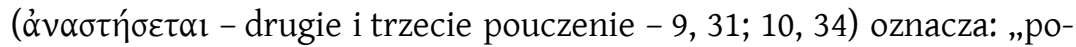
wstać”, „podnieść się”, „zmartwychwstać”"15. Ewangelista podkreśla zatem, że Syn Człowieczy przezwycięża śmierć dzięki własnej mocy ${ }^{16}$. Do-

12 Por. S. Grasso, Vangelo di Marco..., dz. cyt., s. 234. Autor powołuje się na Leviticus Rabba 18,1 .

13 S. Grasso, Vangelo di Marco..., dz. cyt., s. 234.

14 Por. J. Gnilka, Das Evangelium nach Markus (Mk 8, 27 - 16, 20), Zürich, Düsseldorf $1999^{5}$, s. 16 (Evangelisch-Katholischer Kommentar zum Neuen Testament, t. 2/2).

15 Zmartwychwstanie jako pokonanie śmierci znajduje swe pierwotne tło w powrocie człowieka ze snu do stanu całkowitej świadomości.

${ }_{16}$ Mateusz stosuje w miejscach paralelnych odpowiednio czasowniki: $\varepsilon \gamma \varepsilon \rho \theta \tilde{\eta} v \alpha l$ (bez-

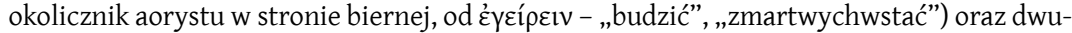
krotnie $\dot{\varepsilon} \gamma \varepsilon \rho \eta \dot{\sigma \varepsilon \tau \alpha ı ~(c z a s ~ p r z y s z ł y ~ s t r o n y ~ b i e r n e j, ~ r o ́ w n i e z ̇ ~ o d ~ \varepsilon ̇ \gamma \varepsilon i ́ p \varepsilon ı v) . ~ E w a n g e l i s t a, ~ u z ̇ y-~}$ wając konsekwentnie strony biernej (passiva theologica), zaznacza, że zmartwychwstanie Jezusa jest dziełem Boga. Łukasz zaś stosuje w miejscach paralelnych odpowiednio: przyto-

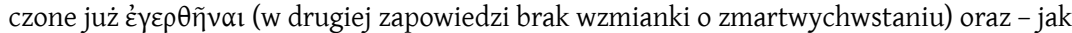

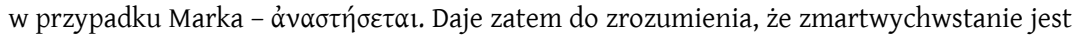

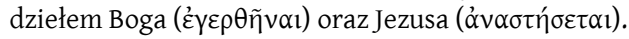


strzegamy zatem podwójną wartość tytułu „Syn Człowieczy”. Z jednej strony wyraża ekstremalne poniżenie, $z$ drugiej zaś jest objawieniem boskości Jezusa, zwycięzcy śmierci. Marek poświęca jednak więcej miejsca cierpieniu i śmierci Syna Człowieczego niż zwycięstwu, które Go czeka na końcu Jego drogi.

Jedynie Ewangelia Markowa zaznacza, że Jezus wypowiedział te sło-

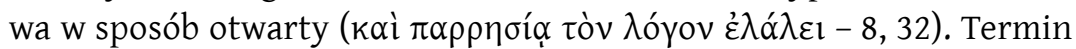

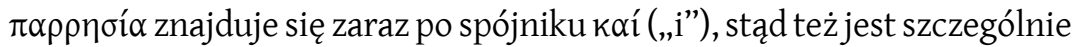

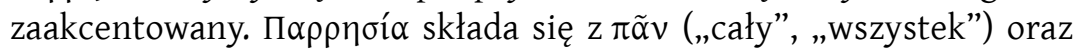
¡́̃̄ı („mówienie”, „mowa”) i oznacza mówienie o wszystkim, czyli mowę, która nic nie przemilcza i nic nie ukrywa ${ }^{17}$. Wyraża zatem szczerość, otwartość, odwagę. Jezus mówi więc o swym losie zupełnie otwarcie, z odwagą.

\subsection{Reakcja Piotra i odpowiedź Jezusa}

Reakcja Piotra nie znajduje paraleli u synoptyków. Piotr bierze na bok Jezusa. Marek nie przytacza słów Piotra, akcentuje natomiast sposób,

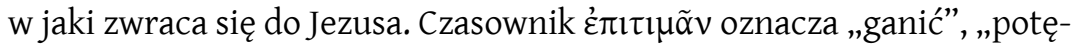
piać”, „besztać”. Za pomocą tego słowa Jezus zwracał się między innymi przeciwko demonom (por. Mk 1, 25; 3, 12; 9, 25). Piotr gani Jezusa, zachowuje się tak, jakby dostrzegał w Nim demona.

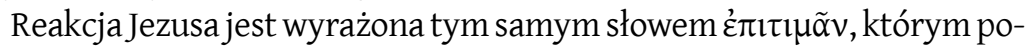
służył się wcześniej Piotr. Teraz Jezus pragnie uwolnić go od ducha konte-

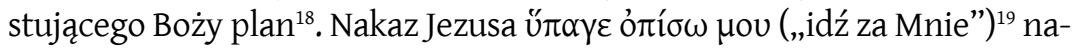
wiązuje do Piotra, który wysunął się przed Jezusa, aby sprzeciwić się Jego losowi. Jezus rozkazuje mu, aby zajął miejsce ucznia, czyli był za Mistrzem.

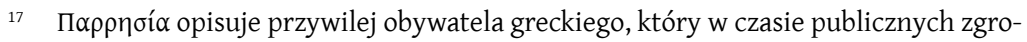
madzeń mógł wyrazić swoją opinię. Por. S. Grasso, Vangelo di Marco..., dz. cyt., s. 233.

18 Piotr usiłuje odłączyć Jezusa od Bożego planu i chce narzucić Mu własny. Wyraźnie sprzeciwia się temu tradycja biblijna. W Iz 55, 8-9 czytamy: „myśli moje nie są myślami waszymi ani wasze drogi moimi drogami - wyrocznia Pana. Bo jak niebiosa górują nad ziemią, tak drogi moje - nad waszymi drogami i myśli moje - nad myślami waszymi”.

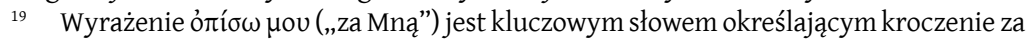
Jezusem. Pojawia się w opisie powołania Piotra i Andrzeja, Jakuba i Jana (por. Mk 1, 17. 20). 
Mistrz zna drogę, natomiast uczeń powinien dać się prowadzićc ${ }^{20}$. Piotr poprzez swoją postawę buntu zostaje nazwany szatanem. Szatan jest wrogiem, głównym przeciwnikiem Boga, tym, który przekręca prawdę i wypowiada kłamstwo ${ }^{21}$. Piotr zachowuje się jak szatan. W sposobie swojego myślenia jest w opozycji wobec Boga. Przeciwstawia się „rzeczom Boga”

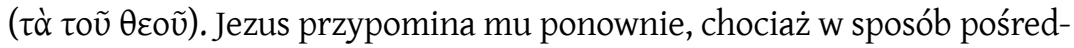
ni, że los Syna Człowieczego jest określony przez Boga. Wszelki opór przeciw temu losowi jest równocześnie sprzeciwem wobec Boga. Mimo że wypływa ze spontanicznych odruchów serca, to jednak stawia kontestatora po stronie szatana, pierwszego sprawcy tego typu opozycji ${ }^{22}$.

Pierwsze pouczenie o losie Syna Człowieczego staje się jeszcze bardziej wyraziste, gdy się uwzględnia jego kontekst dotyczący wyznania Piotra: „Ty jesteś Mesjasz" (Mk 8, 29). Piotr jest do głębi przekonany o mesjańskości Jezusa i jednocześnie ukazuje, jak ma zafałszowaną tę koncepcję. Zgodnie z żydowskimi spekulacjami wierzył w mesjasza zwycięskiego, chwalebnego, który miał wyzwolić Izraela z rzymskiej niewoli. Reakcja Piotra pokazuje, jak konieczne jest pouczenie ze strony Jezusa. Ponadto objawia także stan ducha uczniów i dowodzi, że potrzebują formacji, ponieważ nie są gotowi, aby pójść drogą cierpień przygotowanych dla Syna Człowieczego.

\section{Kluczowe fakty z męki Syna Człowieczego (Mk 9, 30-32)}

Drugie pouczenie dokonuje się w kontekście przechodzenia Jezusa przez Galileę. O Jego podróży nikt nie powinien się dowiedzieć (por. 9, 30), ponieważ - jak sam wyzna w 10, 32 - idzie do Jerozolimy. Nie chce więc, aby Go ktoś zatrzymywał.

20 Por. K. Stock, Il cammino di Gesù verso Gerusalemme..., dz. cyt., s. 46.

${ }^{21}$ We wczesnym chrześcijaństwie fałszywi nauczyciele byli postrzegani jako narzędzia synów szatana (por. Rz 16, 17-20; 2 Kor 11, 13-15; Dz 13, 10; Ignacy Antiocheński, List do Filadelfian, [w:] Pierwsi świadkowie. Pisma Ojców Apostolskich, Kraków 1988², 6, 1n). Można więc mówić o wpływie szatana na błądzących.

${ }^{22}$ Por. K. Stock, Il cammino di Gesù verso Gerusalemme..., dz. cyt., s. 48. Nagana skierowana do Piotra i przytoczona także przez Mateusza dowodzi, że Ewangelie nie idealizują tych, którzy są wokół Jezusa. Uczniowie są opisani w swych reakcjach i postawach w sposób realistyczny. Por. S. Grasso, Vangelo di Marco..., dz. cyt., s. 234. 
Spośród trzech pouczeń na temat przyszłego losu Syna Człowieczego drugie jest najkrótsze: „Syn Człowieczy będzie wydany w ręce ludzi, [ci] zabiją Go, a zabity zmartwychwstanie po trzech dniach" $(9,31)$. Pouczenie wymienia jedynie zasadnicze fakty z męki Syna Człowieczego, nie wymienia odpowiedzialnych za Jego śmierć.

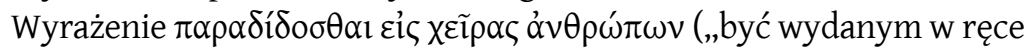
ludzi") ${ }^{23}$ oznacza być znienawidzonym, wystawionym na okrucieństwo i ludzką podłość. Konsekwencje takiego wydania są widoczne w sposób wzorcowy w męczeńskiej śmierci Jana Chrzciciela (por. Mk 6, 17-29). Strona bierna $\pi \alpha \rho \alpha \delta i ́ \delta o \tau \alpha l$ (,,będzie wydany”) ${ }^{24}$ zawiera w sobie myśl, że tego typu działanie nie dokonuje się poza Bożą obecnościąa ${ }^{25}$. Stanowi bowiem passivum theologicum. Skandal męki polega na tym, że Bóg wydaje Syna Człowieczego brutalnej przemocy ludzi. Podwójne stwierdzenie dotyczące śmierci Jezusa ponownie akcentuje ludzką nikczemność.

Reakcją uczniów na pouczenie Jezusa jest niezrozumienie. Uczniowie nie potrafią odnaleźć się w usłyszanych słowach. Boją się możliwości otrzymania dalszych szczegółów na temat Jego cierpienia. Pozostają więc milczący. Wprawdzie idą za Jezusem, ale ich postawa wskazuje, że wewnętrznie są od Niego daleko.

\section{Szczegóły związane z pasją Syna Człowieczego (Mk 10, 32-34)}

Trzecie pouczenie po raz pierwszy wymienia Jerozolimę jako kres

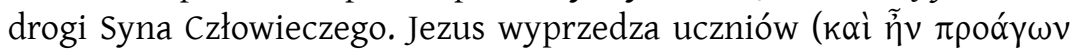

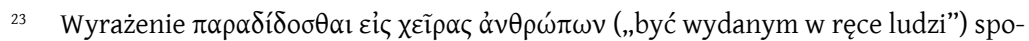
tykamy w mowie proroka Jeremiasza przeciwko Egiptowi (por. Jr 26 (TM 46), 24) oraz w Dn LXX 7, 25, gdzie czytamy o świętych Najwyższego wydanych w ręce prześladowcy Antiocha Epifanesa.

${ }^{24}$ Czasownik $\pi \alpha \rho \alpha \delta 1 \delta o ́ v \alpha 1$ („,wydawać”, ,przekazywać”) występuje w czasie teraźniejszym, który przyjmuje znaczenie czasu przyszłego. П $\alpha \rho \delta \delta$ ióv $\alpha$ streszcza w sobie bolesny los Jana Chrzciciela (por. 1, 14), Jezusa (por. np. 3, 19; 9, 31; 14, 10; 15, 1) oraz uczniów (por. 13, 9. 11. 12).

${ }_{25} \Pi \alpha \rho \alpha \delta 1 \delta o ́ v \alpha \mathrm{l}$ (,wydawać”) jest zastosowany w sensie teologicznym w: $2 \mathrm{Krl} \mathrm{21,14;}$ Ps 106 (LXX 105), 41, zaś w sensie świeckim, jurydycznym w: Jr 33 (TM 26), 24; Dz 21, 11; 28, 17. Opisuje opresyjne postępowanie (por. Kpł 26, 25; Pwt 1, 27; 2 Krl 21, 14; Hi 9, 24; 16, 12. Por. S. Grasso, Vangelo di Marco..., dz. cyt., s. 246. 


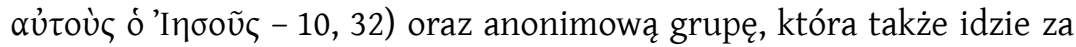
Nim. Obydwie grupy wyróżniają analogiczne przeżycia: przerażenie i strach. Czasowniki $\theta \alpha \mu \beta \varepsilon i \tilde{\sigma} \theta \alpha l$ („być przerażonym”) oraz $\varphi \circ \beta \varepsilon \tilde{\sigma} \sigma \theta \alpha l$ („,bać się”) należą do pola semantycznego wyrażającego emocje i są zastosowane w tekście w czasie przeszłym niedokonanym. Podkreślają zatem, że strach jest trwającym stanem ducha zarówno uczniów, jak i tych, którzy kroczą za Jezusem.

Bezpośrednimi adresatami pouczenia są uczniowie, których Jezus bierze na bok (por. Mk 4, 10; 6,31-32). Trzecie pouczenie jest najbardziej szczegółowe: „Syn Człowieczy będzie wydany arcykapłanom i uczonym w Piśmie, ci skażą Go na śmierć i wydadzą poganom. I będą z Niego szydzić, oplują Go, ubiczują i zabiją, a po trzech dniach zmartwychwstanie" $(10,33-34)$.

Czasownik $\pi \alpha \rho \alpha \delta$ I $\delta o ́ v \alpha l$ („wydać”) pojawia się w trzecim pouczeniu dwukrotnie: raz w stronie biernej w relacji do przywódców żydowskich i raz w stronie czynnej w odniesieniu do pogan. Strona bierna $\pi \alpha \rho \alpha \delta o \theta \eta ́ \sigma \varepsilon \tau \alpha l$ (,będzie wydany”) wskazuje, że za wydaniem Jezusa arcykapłanom i uczonym w Piśmie ${ }^{26}$ kryje się znów działanie Boga (passivum theologicum), któ-

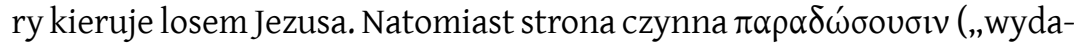
dzą") podkreśla jeszcze raz odpowiedzialność sanhedrynu ${ }^{27}$ za wydanie Jezusa na śmierć (por. 14, 64) i przekazanie Go poganom (por. 15, 1). Zawinione postępowanie ludzi oraz plan Boży łączą się, nie niwecząc przy tym ani wolności Boga, ani wolności ludzi.

Następstwem wydania Jezusa są drwiny (por. Mk 14, 65; 15, 16-20. 29-32), oplucie (por. 14, 65; 15, 19), biczowanie (por. 15, 15) oraz zabicie. W odróżnieniu od Mateusza Marek (podobnie jak Łukasz) nie precyzuje faktu, że śmierć Syna Człowieczego dokona się przez ukrzyżowanie. Ten najbardziej haniebny rodzaj śmierci zawarł w ogólnym czasowniku

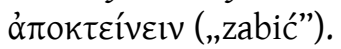

Z trzeciego pouczenia wynika, że Jezus dostrzega swój koniec ze wszystkimi szczegółami i nie wycofuje się z obranej drogi. Natomiast ucznio-

26 Nie są zatem wymienieni sprawcy wydania, ale jedynie adresaci, czyli arcykapłani i uczeni w Piśmie.

${ }^{27}$ W odróżnieniu do pierwszego pouczenia nie wymienia się starszych (por. 8, 31). 
wie, mimo że po raz trzeci słyszą słowo o zbliżających się cierpieniach Syna Człowieczego, w dalszym ciągu zachowują dystans i niezrozumienie. Myślą o przywilejach (por. 10, 37), jak czytamy w perykopie następującej zaraz po trzecim pouczeniu (por. 10, 35-40), a nie o współodczuwaniu z Jezusem.

\section{Zastępczy charakter pasji Syna Człowieczego (Mk 10, 45)}

Cierpienia Syna Człowieczego objawione w trzech pouczeniach streszcza zdanie stwierdzające cel Jego misji: „dać swoje życie na okup za wielu”. Cytat ten pojawia się w perykopie występującej niemalże zaraz po trzecim pouczeniu o losie Jezusa. Ma z nią pośredni związek (por. ww. 35. 36). Jego kontekst dotyczy służby i tłumaczy, że ostateczny jej kształt w przypadku Jezusa wyraża się w oddaniu swego życia,

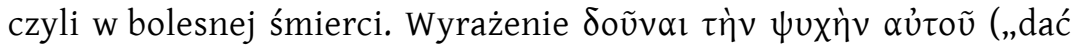
swoje życie") oznacza w Mk 10, 41-45 (por. par. Mt 20, 28) okrutną śmierć28 i znajduje swój odpowiednik także w Ewangelii Janowej w po-

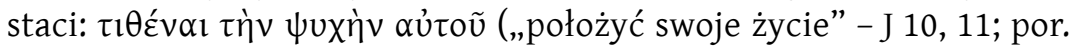
10. 15. 17. 13, 37. 38; 15, 13).

Syn Człowieczy zmierza zatem w kierunku śmierci w sposób dobrowolny i zdecydowany - jak to już zauważyliśmy w trzech pouczeniach

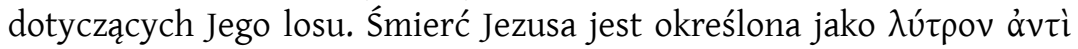

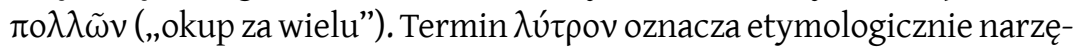
dzie, które pozwala kogoś „uwolnić”, „wyzwolić”. Tego typu sens sugeruje związany z $\lambda u ́ \tau \rho o v$ czasownik $\lambda v \tau \rho o \tilde{\sigma} \sigma \theta \alpha$ ı opisujący między innymi wyzwolenie Izraelitów z niewoli egipskiej (Pwt 7, 8; 9, 26; 13, 6). Poza tym

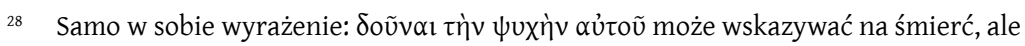

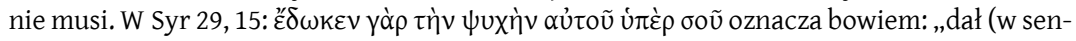

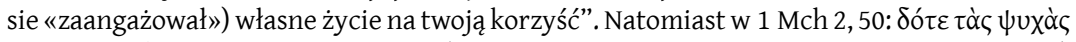

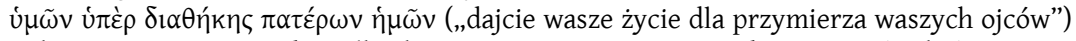
wskazuje na wezwanie do walki skierowane przez Matatiasza do jego synów, które zawiera w sobie ryzyko utraty życia. W naszym jednak przypadku ewentualność ustępuje pewności. „Dać swoje życie” należy rozumieć jako śmierć. Por. S. Légasse, Marco, Roma $2000^{2}$, s. 541 (Commenti Biblici). 


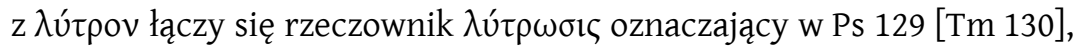
7 wyzwolenie z grzechów.

Stary Testament stosuje termin $\lambda u ́ \tau$ úv w kontekście odszkodowania pieniężnego, dzięki któremu można ustrzec się przed karą śmierci (por. Wj 21, 30; Lb 35, 31.32) oraz w sensie ceny wykupu za ziemię (Kpł 25, 24. 26) lub za ubogiego, który się sprzedał jako niewolnik (por. Kpł 25, 47-55). We wszystkich tych przypadkach jest obecna idea zastępstwa. Staje się ona tym bardziej wyraźna, gdy po $\lambda u ́ \tau$ pov pojawia się przyimek ởví (,zamiast”, „w zamian za") ${ }^{29}$.

Wyrażenie „dać swoje życie jako okup za wielu” interpretuje więc bolesną śmierć Jezusa na Kalwarii w sensie „zastępstwa”" oddaje swoje życie jako okup „zamiast wielu”. „Wielu” ma tutaj sens uniwersalny i oznacza świat ludzi ${ }^{31}$. Tego typu znaczenie znajduje swoje potwierdzenie w $1 \mathrm{Tm}$ 2, 6, gdzie w kontekście pośrednictwa Jezusa między Bogiem a ludźmi czytamy w dosłownym brzmieniu: „który wydał siebie

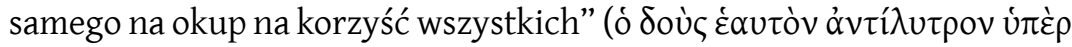
$\pi \alpha ́ v \tau \omega v)^{32}$.Efektem śmierci Jezusa w zastępstwie grzesznej ludzkości jest wyzwolenie człowieka - niewolnika grzechu.

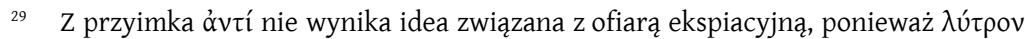
nie ma wydźwięku kultycznego. Niekiedy dostrzega się w naszym zdaniu echo z Iz 53, 10:

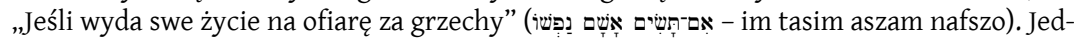

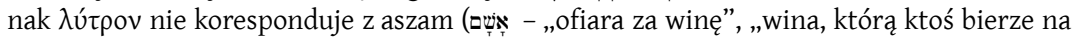
siebie") i nigdy go nie tłumaczy. Kontaktu z tekstem Deutero-Izajasza można dopatrywać się jedynie w 53, 12, gdzie czytamy, że Sługa „poniósł grzechy wielu”, zapowiadając w ten sposób uniwersalną, zbawczą misję Syna Człowieczego. Por. S. Légasse, Marco, dz. cyt., s. 541.

30 S. Légasse, Marco, dz. cyt., s. 542.

31 Egzegeci jednomyślnie zgadzają się, że jest to pojęcie uniwersalne w sensie „wszyscy”. Por. H. Frankemölle, Mattäus Kommentar 2, Düsseldorf 1997, s. 296.

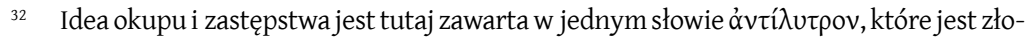
żeniem z przytaczanych już wcześniej w tekście: przyimka ơv $\imath_{i}$ („zamiast”) oraz rzeczownika $\lambda u ́ \tau \rho o v($,okup”). 


\title{
Summary
}

\author{
Humanity and Divinity of the Son of Man in His Passion, Death \\ and Resurrection. Three Teachings of Jesus on His Passion \\ from Mark's Perspective.
}

The article refers to Mark's Christology, that has a primitive character and expresses itself, inter alia, under the title "Son of Man". The author presents it as a specific aspect referring to three teachings of Jesus on his dramatic fate (Mark 8,31-32, $9,30-32,10,32-34)$ and also in the statement of Jesus where He speaks about the giving of his life as a ransom for many (cf. Mark 10, 45). The analysed title "Son of Man" combines humiliation and glory. Mark indeed stresses in each of the three teachings that the Son of Man will resurrect by his own power. His death is a liberation of man - the slave of sin. Therefore, the Evangelist showed indirectly that in the title "Son of Man" are hidden both the humanity and divinity of Jesus, despite the fact that Mark put more emphasis on Jesus' tormented humanity.

Keywords: Humanity of Jesus, destiny of the Son of Man, humiliation of Jesus, lack of understanding from the disciples, "give his life", Resurrection of Jesus

\section{Człowieczeństwo i bóstwo Syna Człowieczego w Jego męce, śmierci i zmartwychwstaniu. Trzy pouczenia Jezusa o swej pasji w ujęciu Markowym}

Jezus, pouczając trzykrotnie uczniów o swoim dramatycznym losie oraz ukazując cel swojego życia, posługiwał zawsze się tytułem „Syn Człowieczy”. Zawarł w nim swoje człowieczeństwo naznaczone wyjątkowym cierpieniem. Ukazał w ten sposób swoim uczniom, że Jego mesjańskość wyrazi się nie w triumfie, ziemskiej chwale, lecz przejdzie przez ekstremalne poniżenie, wzgardę i śmierć. Jezus - człowiek zmierzał do swego kresu w sposób zdecydowany i umotywowany. Klęska Syna Człowieczego, chociaż miała swoją widzialną przyczynę w ludzkich sprawcach, to jednak wypływała z planu Bożego, w którym zostały przewidziane zastępcza śmierć Jezusa za wszystkich ludzi oraz powstanie z martwych Syna Człowieczego.

Wszystkie trzy pouczenia Jezusa podkreślają, że ostateczne zwycięstwo jest właśnie Jego dziełem. W ten sposób ewangelista Marek, który wyeksponował w losie Syna Człowieczego przede wszystkim cierpienia Jezusa, zwrócił także uwagę na Jego bóstwo. Tym samym ukazał, że człowieczeństwo i bóstwo Syna człowieczego łączą się ze sobą w sposób nierozerwalny.

Słowa kluczowe: człowieczeństwo Jezusa, los Syna Człowieczego, poniżenie Jezusa, niezrozumienie przez uczniów, „dać swoje życie”, powstanie z martwych Jezusa 


\section{Bibliografia}

Bartnicki R., Ewangeliczne zapowiedzi męki, śmierci i zmartwychwstania w świetle kryteriów autentyczności logiów Jezusa, „Collectanea Theologica” 51 (1981), fasc. II, s. 53-64.

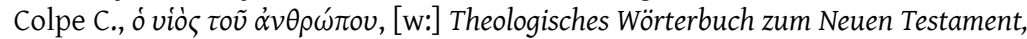
in Verbindung mit zahlreichen Fachgenossen, hg. von G. Friedrich, t. 8, Stuttgart 1969, s. 403-481.

Frankemölle H., Mattäus Kommentar 2, Düsseldorf 1997.

Gnilka J., Das Evangelium nach Markus (Mk 8, 27 - 16, 20), Zürich-Düsseldorf $1999^{5}$ (Evangelisch-Katholischer Kommentar zum Neuen Testament, t. 2/2).

Grasso S., Vangelo di Marco. Nuova versione, introduzione e commento, Milano 2003 (I Libri Biblici, Nuovo Testamento, t. 2).

Ignacy Antiocheński, List do Filadelfian, [w:] Pierwsi świadkowie. Pisma Ojców Apostolskich, Kraków $1988^{2}$.

Kasiłowski P., Zapowiedź śmierci Jezusa a postawy uczniów w Mk 8, 27- 10, 52, „Bobolanum" 8 (1997), s. 111-125.

Langkammer H., Ewangelia według św. Marka. Tłumaczenie, wstęp i komentarz, Lublin $2004^{2}$ (Pismo Święte Nowego Testamentu w Przekładzie z Języków Oryginalnych).

Langkammer H., Ewangelia według św. Marka. Wstęp - przekład z oryginału - komentarz, Poznań 2007 (reprint z 1977) (Pismo Święte Nowego Testamentu, t. 3/2).

Légasse S., Marco, Roma 2000² (Commenti Biblici).

Mień A., Syn Człowieczy, Warszawa 1994.

Parchem M., Księga Daniela, Częstochowa 2008, s. 471 (Nowy Komentarz Biblijny, Stary Testament, t. 26).

Sławiński H., Przepowiadanie Chrystusowego krzyża, Warszawa 1997.

Stock K., Il cammino di Gesù verso Gerusalemme. Marco 8, 27 - 10, 52, Roma 1989.

Stock K., Alcuni aspetti della cristologia Marciana, Roma 1989. 
